\title{
Bharatanatyam as a Global Dance: Some Issues in Research, Teaching, and Practice
}

\author{
Avanthi Meduri
}

$T^{2}$ he promise of critical liberation that postcolonial and transnational perspectives offer by urging us to think the complex imbrication of the global in the local remains an unfulfilled promise in South Asian dance scholarship. I will elaborate this point by describing the global thrust of Rukmini Devi's art and education movement, which could not be recuperated within the territorializing intellectual framework of Indian nationalism, and explain why she, in fact, manifests herself as a discursive failure in standard scholarly accounts of Bharatanatyam in the United States.

\section{Part I}

Bharatanatyam manifests itself as a world form today, quite like Ballet, albeit with a different genealogy. It is researched in western academic institutions in the United Kingdom, Europe, the United States, Canada, Australia, as well as in India, Sri Lanka, Singapore, and Malaysia. Practitioners and dance scholars organize international conferences focused on Bharatanatyam all over the world today, and the Dance Studies Program at Roehampton, supported by a grant from the Arts and Humanities Research Board (AHRB), has assumed a leadership role in providing a new, global profile for the dance. ${ }^{1}$

But the globality of Bharatanatyam, intricately linked with the global discourses of colonial modernity is still, in my opinion, not on the research and curricular agendas of dance departments in the United States. This initiative was deferred because the small

Avanthi Meduri is Reader in the Dance Studies Programme at Roehampton University, London, and Convener of the new MA/PGDip in South Asian Dance Studies. She received her Ph.D. from the Department of Performance Studies, New York University and held visiting teaching appointments at UCLA (1993-1996) and in the Department of
Performance Studies, Northwestern University (1997-2000). Trained since childhood in Bharatanatyam and Kuchipudi, Meduri works in the field of dance education, women's theatre and performance. She is a Ford Scholar and the Academic and Artistic Director of the newly founded Centre for Contemporary Culture, New Delhi. 
group of dance scholars working on the history of the form in the I980s researched the twentieth century revival of Sadir as Bharatanatyam primarily from within the framework of Indian nationalism and a local modernity perspective rather than the spatial worldview of global modernity. Both modernities, however, defined the history and identity of Bharatanatyam since the nineteenth century, continuing into the present.

When we began our investigations into the history of the dance in the United States in the I980s, we were alerted to the presence of the two modernities and their different realization within the framework of British colonialism in the nineteenth century, and Indian nationalism in the twentieth century. ${ }^{2}$ To mark the differences between the two modernities, we theorized nineteenth-century colonial modernity as representing a spatial, disruptive, and alien modernity, unsympathetic to local issues involved in the cultural production of the arts. We contrasted this alien rationality with the "enlightened" intervention of Indian nationalists, known as "revivalists" who rebutted colonial modernity and enabled the local revival of Indian performing arts in the twentieth century.

In my doctoral thesis, I described how colonial modernity displaced and hybridized the life and artistic practices of hereditary women practitioners known as devadasis (temple dancers), who sang and danced in the courts and temples of South India in the nineteenth century. I focused attention on the translational practices of British colonialism and Orientalism and described how these hegemonic practices hybridized the vernacular identity and artistic practices of devadasi women by misnaming them as "temple prostitutes" and "nuns." Both the devadasi, and her dance known as Sadir, were thus transnationalized during the period of British rule in India in the nineteenth century. ${ }^{3}$

Yet when we researched the twentieth-century revival of Bharatanatyam, we took our cue from the pioneering research of Amrit Srinivasan (1983; 1985), and described it not from within the global modernity perspective of colonialism but from within the ideological framework of Indian nationalism and a "local" modernities perspective. We focused attention on Rukmini Devi, a pioneer in the twentieth century revival of Bhartanatyam, and examined her work selectively from within the local temporality of Indian nationalism and hailed her as Indian nationalist. But Rukmini Devi was not just a "nationalist," but also a global Theosophist who worked on behalf of the transnational worldview of the Theosophical Society through her long and distinguished career between I920-I986. The local framework of Indian nationalism, in which we recuperated the work of Rukmini Devi, in other words, provincialized and localized the transnational work and vision of Rukmini Devi.

In my own doctoral study, I sketched the story of Rukmini Devi's intercultural marriage to Englishman George Sydney Arundale in 1920, described how Theosophist Annie Besant, who served as second President of the Theosophical Society, groomed Rukmini Devi to be her spiritual daughter and announced her as the leader of the World Mother movement, conceived as a parallel movement to the World Teacher movement in the I920s. ${ }^{4}$ Yet I did not examine, with any great detail, Rukmini Devi's grooming within the Theosophical Society between I920-I933, her ambivalent incorpo- 
ration into the Society after the demise of Annie Besant in I933, nor her final expulsion from the Society after the demise of George Arundale in I950. I bracketed her work as global Theosophist because I was more interested in her as Indian "nationalist" and the unique manner in which she institutionalized Bharatanatyam in her world-renowned institution known as Kalakshetra, followed by the second institutionalization of the arts sponsored by the Indian nation-state in the $1950{ }^{5} .^{5}$ As noted by the authors of Localizing Knowledge in a Globalizing World, "a great deal of postcolonial theory emerges from a close familiarity with particular regions and is committed to interdisciplinary, contextually grounded work" $(2003,8)$.

What needs to be emphasized, however, is that Rukmini Devi exceeded the denominational category of the "nationalist" and continued to work on behalf of the transnational worldview of the Theosophical Society, even after the historic break with the Society. She served as the head of the Theosophical center in Huizen, contested elections for the Presidency of the Theosophical Society not once, but thrice, and was repudiated on all three occasions. Despite these rebuffs, Rukmini Devi never stopped thinking of herself as a Theosophist, endeavoring until the very end of her life to uphold the legacies of the Theosophical Society bequeathed to her by Annie Besant and George Arundale. One year before her death in 1986, Rukmini Devi narrated her life story into a taperecorder, (there is no biography on Rukmini Devi), likened herself to Annie Besant, her spiritual mother, spoke of the r950s disassociation and said:

These forty years, since Arundale died in 1945, have been a time of great struggle and stress. If I did not have the inner conviction that both he and Dr. Besant were there in spirit to protect the work, I do not think I could have carried on. The emphasis on my own life changed from the personal to the impersonal in the r950. Some people, while interpreting Ramayana, have said that Sita who was abducted by Ravana and later entered the fire was only a Maya Sita and not the real Sita. This is how I feel about myself. I had to somehow carry on because they had believed in my work and the best way I could prove my love for them was to make a success of it. There were so many personal attacks on me, hurtful gossip, many unpleasant things. It was my karma I guess. . . . Dr. Besant used to say, when she was attacked during her last days - that she could count the number of true friends on the fingers of one hand. That was how it was. I understand now how true it is. $(2003,65)$

If we began our studies in South Asian dance history by examining the macro and spatial processes of colonial modernity in the nineteenth century, our analytic frame shrunk to detail the local dance revival of the twentieth century, and focused restrictively on critiques of Indian nationalism, rather than on the large issues of comparative modernities including sociological studies of state, patriarchy, and national/global institutions of patronage in which Bharatanatyam circulates even today. ${ }^{6}$ I will now resketch Rukmini Devi's well-known story by repositioning it within the double framework of global and Indian modernity, simultaneously. 


\section{Repositioning Rukmini Devi within a Global/Local Framework}

Most South Asian scholars know that Rukmini Devi was a central figure in the transnational avant-garde movement of the Theosophical Society. She married George Sydney Arundale, was made President of the All India Federation of Young Theosophists and World Federation of Young Theosophists, and traveled the world in the first thirteen years of her grooming within the Society between $1920-\mathrm{I} 933 .{ }^{7}$ On one of her intercultural travels around the world she met Anna Pavlova, and learned Ballet from Cleo Nordi, a member of Anna Pavlova's troupe. ${ }^{8}$

But Rukmini Devi returned to India in 1933, learned Sadir from traditional male teachers and devadasis, renamed the dance as Bharatanatyam, and performed it on the occasion of the Diamond Jubilee Celebrations of the Theosophical Society, in 1935. On this occasion, she used stage lighting, imported from British stagecraft, and recostumed, restaged, and theatricalized the dance in the manner of Isadora Duncan. If the model international classical dance tradition for Rukmini Devi was Ballet, the model Indian classical dance tradition was the Tanjore court style of dance that she learned from the great guru Meenkshi Sundaram Pillai (Ramnarayan 1984, 29; Sarada I996, 20). ${ }^{9}$ All through her life, Rukmini Devi juxtaposed Bharatnatyam and Ballet, developing an aesthetic for Kalakshetra Bharatanatya that could be transmitted as India's own classical dance tradition.

One year after her debut Rukmini Devi founded the International Academy of Arts, (later renamed as Kalakshetra) to enable the revival of Bharatanatyam. She yoked the art revivial with the educational goals of the Besant Memorial School that she established in $1934 .{ }^{10}$ In the first stage of the revival between I930-I940, Rukmini Devi founded three other institutions including the Crafts and Weaving Centre, Dr. U.V. Swaminatha Iyer (Tamil) Library; and the Arundale Montessori Teachers Training College. ${ }^{11}$ All five institutions were housed in different wings of the huge estate property of the Theosophical Society in Adyar. Rukmini Devi worked within the domain of her five institutions and developed a pioneering, art and education movement that was both "local" and transnational simultaneously.

To realize her art and education vision, Rukmini Devi invited international educators and traditional dance and music teachers to teach in the different institutions. She collaborated with both and developed a multicultural and cosmopolitan world for Bharatanatyam that exceeded standard anthropological definitions of the local and "national" as early as the 1940s. ${ }^{12}$

Anthony King has explained that "[ $t]$ he first substantial encounter between Europe and non-Europe, between capitalist, and pre-capitalist, between white and non-white peoples took place in what were to become the colonies, not the metropole. These encounters were constructed under the very specific conditions of colonialism and were largely products of the specific social and spatial conditions of colonial cities" (1997, 8). Rukmini Devi worked within the worldview of colonialism and developed what Mike Featherstone describes as a "Third Culture," that facilitated transcultural communication (1990, 9). In 1945, she conceptualized a World Culture vision for Bharatanatyam 
that Dr. Besant had commissioned her to realize for the Theosophical Society in I925. ${ }^{13}$

But Rukmini Devi's expanding vision was suddenly arrested, reversed, and displaced by the promulgation of what came to be known as the Theosophical Society's Policy of Disassociation in I950. Without going into details about the policy, the Disassociation explained why Rukmini Devi's artwork could not be accommodated within the larger intellectual conceptualization of the Society. ${ }^{14}$ The policy stipulated that Rukmini Devi remove her five institutions from the grounds of the Society.

Undaunted by the crisis, Rukmini Devi purchased a hundred acres of land in Tiruvanmaiyu, adjoining the Adyar estate of the Theosophical Society, and re-housed her five institutions in this new locality in the I96os. But she refused the Disassociation by subversively constituting another conceptual framework which she called the Besant Cultural Centre, and incorporated her five institutions into this new umbrella formation. ${ }^{15}$ It took Rukmini Devi thirteen years to move her centres and re-house them in the second estate.

In Translocal Modernities (forthcoming), I mark this moment of rupture and displacement, encompassing thirteen years, as
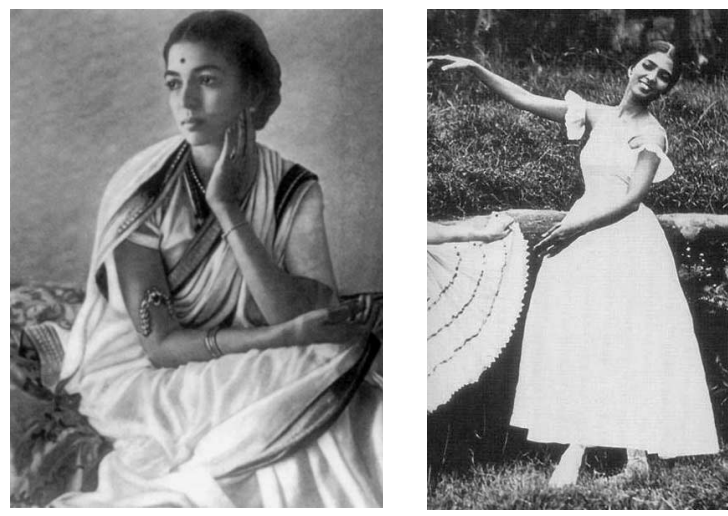

The Two Faces of Rukmini Devi Arundale: Rukmini Devi as Indian woman. Image used courtesy of C. T. Nachiappan Photo Archive. Rukmini Devi as Indian ballerina. Image used courtesy of Kalakshetra Archive. constituting a catastrophic interruption in the history of the five institutions because it was in this place of dislocation that Rukmini Devi was reclaimed as a "nationalist" and projected as Indian ambassador of culture, quite like Martha Graham of the West. ${ }^{16}$ Kalakshetra also assumed an autonomous, national identity, distinct from the cluster of four sister centers, because it was selectively patronized by the national academies established by the state in the I950. Students from all regions of India, Tibet, Sri Lanka, Nepal, Burma, Malaysia, Singapore, and Indonesia came to study in Rukmini Devi's Kalakshetra in the r95os. They were joined by international students from Europe, Australia, America, and England. Completing their education, hundreds of Kalakshetra students, turned into qualified teachers, returned to their respective homes, dispersing themselves in the Indian, Asian, and western worlds to which they belonged. Kalakshetra students are thus scattered across the world today, teaching and performing Kalakshetra Bharatanatyam in schools, colleges, universities, and private training academies located in South Asia, Asia, Europe, England, America, and Australia.

Dance scholars have described Kalakshetra variously as a regional, a local, a traditional, and a national institution. Yet Kalakshetra exceeds or falls short of all these definitions, premised on notions of bounded territory, because of its historical association with the syncretic, transnational vision of the Theosophical Society. I propose that 
we rethink Rukmini Devi's Kalakshetra as a translocal, contemporary arts institution in which Rukmini Devi articulated a transnational history for Bharatanatyam connected to Europe, England, the United States, Canada, Australia, Sri Lanka, Tibet, Singapore, Malaysia, and Indonesia simultaneously. The notion of the translocal "speaks to the challenge of providing an analysis of a global system of social relations without overgeneralizing or establishing hierarchies in which some sites are more global or more important than others. Translocal analysis understands the links between different locations to be unpredictable and contingent rather than representative of a single transnational condition or national identity" (Cvetkrovich and Kellner 1997, 25).

I find this notion of the translocal to be useful as it enables us to examine cultural production not just in terms of the national political struggle but in individual terms and what it means for people like Rukmini Devi to live globally from multiple local contexts. "Like the transnational, the translocal contests the usefulness of the nation as a category of analysis. But it goes still further and announces the need to problematize the locations, spaces, and geographies within which politics and culture intersect" (Cvetkrovich and Kellner 1997, 25).

To properly historicize Rukmini Devi's work and vision, we needed to position it firmly within the global modernity framework of the Theosophical Society in which she worked, and within the translocal institutional context of her Kalakshetra institution. We ought to have begun our interrogation by resisting the temptation to fix her identity as an Indian nationalist or upper-caste Brahmin woman and addressed the complexity of her position as a hyphenated Indian, specifically, an Indian-womanTheosophist. To put it differently, we needed to develop an antiessentalist theory of identity to research the formidable cultural and aesthetic legacy of Rukmini Devi scattered in the global world today. Unfortunately, we were unable to do this in the first stage of the development of postcolonial dance studies because of the uneasy alliances forged between transnational and area studies perspectives. ${ }^{17}$

Our failure to comprehend the work and vision of Rukmini Devi in its translocal scope and dimensionality represents one of the most important political questions on the agenda of dance studies scholarship and is central to what I have described above as the failed promise of postcolonial research on Bharatanatyam. Rukmini Devi, in other words, manifests herself as a discursive failure in standard accounts of Bharatanatyam, as these narratives tell her story from the selective perspective of Indian nationalism.

\section{Part 11: Bharatanatyam as a Global Dance}

It was after completing my doctoral dissertation in 1996, and during my teaching appointment in the Department of Performance Studies at Northwestern University that I was challenged to think specifically about the globality of Bharatanatyam as itself "a condition of modernization and more specifically divergent modernization" (Robertson I995, 3-4).

Since I was hired as a performance studies specialist rather than a dance scholar I had to incorporate my eight years of postcolonial and area studies research on Bharata- 
natyam (Meduri 1988; 1996) within the larger framework of the six interdisciplinary courses that I developed for the Department. Consequently, in my three years at NU, I explored Bharatanatyam with my students in multiple contexts: Interculturalism, Asian Diasporas, Modern and Postmodern Theories of Performance, Global Flows, Postcolonial Theory, and Third World Nationalisms. ${ }^{18}$

Even as I was engaged in developing a global modernities paradigm to discuss the history of Bharatanatyam, I read two articles by the American scholars Matthew Allen (I997) and Janet O'Shea (1998) that, in my judgment, localized the translocal history of the revival by casting it uproblematically within the local framework of Indian nationalism and in the oppositional framework of tradition/modernity. Speaking confidently as insiders to the Balasaraswati style of dance and music, (which they learned from Balasaraswati and her family of students living in the United States and in India), both scholars prioritize Balasaraswati's standpoint by inscribing her within an unbroken lineage of devadasi practitioners, going back to the nineteenth century. They contrast her with Rukmini Devi, who came to Bharatanatyam through the intercultural trajectory of Ballet.

Numerous scholars have critiqued the tradition/modernity model of social change because it "replicates to some extent the presuppositions of Orientalism" (Niranjana, Sudir, Dhareshwar 1993, 5). Others like Gyan Prakash have described how Indian nationalist historiography and South Asia area studies programs in the United States deployed the tradition/change concepts to constitute new intellectual fields of enquiry in the I920s and I950s. By invoking and using contested historical categories, which replicated Orientalist assumptions of India, Allen and O'Shea return dance scholarship to the Orientalist/nationalist paradigm that postcolonial and postnationalist historians have been writing against since the I980s.

I mark this new scholarship as representing the second moment in the development of South Asian dance studies because while the earlier critiques were focused on recovering the repressed history of devadasi women, the new scholarship narrowed the historical investigation by essentializing the postcolonial identity of Balasaraswati and describing her aesthetic vision comparatively with that of Rukmini Devi. While the narrowed focus on two brown women sensationalized the story of the dance revival and made it accessible to audiences in the United States, the analytic frame was historically flawed because Rukmini Devi was neither in conflict nor conversation with T. Balasaraswati. ${ }^{19}$ Both women, besides, worked in different institutional contexts both in India and abroad, a point I will elaborate presently.

I could not envision the force of this new scholarship, and how it would politicize the historical story of the dance revival, when Allen, an ethnomusciologist by training, visited me in California in 1996, requesting a copy of my dissertation in order to write an article on aspects of the revival from the point of view of the traditional community of devadasi practitioners. The article in its published form was more general in its focus. It endeavored to "Rewrite the Script for South Indian Dance," by focusing attention on a single moment in the history of the Kalakshetra institution when Rukmini Devi separated from her male dance teacher and his family in I943. 
One has only to contrast the "tenor of outrage" in which Allen presents his point of view by juxtaposing it with Rukmini Devi's own understated narration of the events. In her narration of the event she explains how "she was deserted [italics mine] by my teachers, including, I am sorry to say my own first teacher Meenakshi Sundaram Pillai" (Ramani 2003, 56). While Allen argues that Rukmini Devi forced traditional teachers to leave her institution, Rukmini Devi describes herself as being abandoned. Which standpoint should we privilege today? ${ }^{20}$

\section{Tradition/Change as Problematic Postcolonial Concepts}

My purpose here is not to refute Allen's claims, but to call attention to the tradition/ change analytic framework that I believe he uses uncritically in his essay. For one thing, Allen conflates the differential gender issues that pressed upon devadasi women in the I940s with those of the male teachers and presents both in a universal frame of "the traditional community." In my dissertation, I described the I940s second phase of the revival as representing a "bitter-sweet transition" by pointing to the emergence of a broader middle-class, separate from Rukmini Devi. I showed how this class, working outside the institutional domain of Kalakshetra, wooed male teachers in the I940s, and helped create new, aesthetic patriarchies in the dance practice.

If Rukmini Devi had created a patrilineal history for Bharatanatyam bypassing devadasi traditions and prioritizing male dance teachers, in what I described as the first stage of the revival in the I930s, she reversed that priority, in the second stage of the I940s, by inviting devadasi women to teach in her institution. Yet the middle class that emerged outside her institution supplemented and supplanted devadasi practitioners by privileging male teachers over devadasis in the I940s. Because Allen conflates devadasi issues with those of the male teachers, he fails to read the internal dynamic of appropriation between male teacher and devadasi, which also fed into the hegemonic forces that marginalized these women practitioners in the r940s.

\section{Balasaraswati and Rukmini Devi in a Binary Frame}

Allen's essay was followed by O'Shea's article published in I998. O'Shea narrowed her analytic frame of tradition/change to focus on the aesthetic legacies of "two towering women that stand at the source [my italics] of twentieth century Bharatanatyam: Tanjore Balasaraswati and Rukmini Devi" $(1998,46)$. She then compares the "instructional and interpretive communities" of the two dancers, "their discrete sets of aesthetic standards and choreographic conventions (57) by arguing that Balasaraswati was affiliated with a school known as the Tanjore court style while Rukmini Devi was associated with a style that she developed at her Kalakshetra school" (46). O'Shea's binary is historically flawed because Rukmini Devi also revived the Tanjore court style of dance in her Kalakshetra institution in the I930s, but refined and aestheticized the court style to articulate a neoclassical, Tanjore court-style Bharatanatyam in 1943.

Whereas almost all of the seven odd sets of binaries that O'Shea invokes to develop 
her comparative critique can be refuted, I prefer to focus on the problems inherent in the binary model itself, an analytic frame that has been subjected to rigorous critique in postmodern, poststructuralist, and feminist discourses and bracketed because of the essentialisms it replicates. In her doctoral dissertation (200I) O'Shea again discusses the two women within the binary framework "of Brahmin Rukmini Devi and devadasi Tanjore Balasaraswati respectively ... so that tensions between the two concerns manifests as a debate between a reformer and traditionalist" (200I, 24). It is this placement of the term "Brahmin" before Rukmini Devi and "devadasi" before Balasaraswati, that I want to critique now because O'Shea uses the prefix to mark originary caste and class differences between the two women.

\section{Balasaraswati and Rukmini Devi As Inside-Outsiders}

Let me begin by saying that Tanjore Balasaraswati was not a "traditional" devadasi. A1though she had her Arangetram (debut performance) at the Amanakshi Amman temple in Kancheepuram, she was never a dedicated temple dancer married by a priest to the god. ${ }^{21}$ She hailed from a family who had served in the court of Tanjavur, but colonial modernization had impacted the family of musicians and dancers to such an extent that they relocated to the Madras Presidency towards the end of the nineteenth century. ${ }^{22}$ "Neither the mother nor grandmother of T. Balasaraswati performed dance, though their female ancestors had been court dancers at Tanjavur. Leaving behind the practice of the dance, the women in this family began to concentrate in the late nineteenth century on vocal or instrumental music" (Allen 1997,68 ). T. Balasaraswati's mother and grandmother thus intended for Balasaraswati to be a musician rather than a dancer.

It is true that Balasaraswati was fiercely proud of her mother, her grandmother, her devadasi ancestors and their artistic achievements (O'Shea I998, 48), but she was really an inside-outsider to the devadasi traditions because she had not been dedicated to the temple or married to the god. We thus ought not describe her as a centered subject located fully within the social practice of devadasis, but rather as one whose identity was under erasure and discontinuous with her ancestral and familial lineage. Balasaraswati, in other words, was neither a true devadasi, nor was she not a devadasi.

Similarly, Rukmini Devi described herself as a traditional dancer because she worked on behalf of the twentieth-century revival of traditional Indian dance. But she too, like Balasaraswati, was not an insider to devadasi traditions because she was a Brahmin woman. Yet Rukmini Devi was not a "true Brahmin." She too was discontinuous with her own ancestral and familial history because she was married to an Englishman, George Sydney Arundale, who was also a Bishop of the Liberal Catholic Church. Like Balasaraswati, Rukmini Devi's identity was under erasure because she was neither a true Brahmin nor was she not a Brahmin.

The contingency of the double negative-being neither inside nor entirely outside their own respective familial histories-defined the lives of the two women, canceled and put under erasure, their unitary identities. Yet it is this cancellation, paradoxically, that permits us to continue to read them in the place of the prefix, whether it be the 
devadasi or Brahmin woman, which they could never fully inhabit in their lives. Citing Derrida, Stuart Hall has described this approach as thinking at the limit, as thinking in the interval, a sort of double writing. I propose it as another antiessentialist way in which we might think the complex processes of subject formation that fractured and defined the identities of T. Balasaraswati and Rukmini Devi respectively. It is worth repeating that "what this decentering requires is not the abandonment or abolition of the subject but a reconceptualization-thinking it in its new displaced or decentered position within the paradigm" (Hall 1996,2$)$.

\section{Heterogenizing "Tradition"}

Because both women hailed from different class and caste backgrounds, they used the resources of their own history, language, and culture selectively to invent different traditions for Bharatanatyam. Yet they both emerged as historical subjects within a shared but unevenly accented frame of Indian modernism in the r930s. While Balasaraswati was presented by V. Raghavan and other scholars as a traditional dancer on the platform of the Madras Music Academy in I933, Rukmini Devi was also presented as a traditional dancer by her husband George Sydney Arundale in her debut performed in the Adyar theatre, located within the huge estate of the Theosophical Society. Both women performed an old dance known as Sadir under the new name of Bhartanatyam, given to the dance by scholars like V. Raghavan and worked as "traditional dancers" within the modern framework of Indian nationalism over the fifty-year period of the revival between $1930-1980 .{ }^{23}$

If Balasaraswati worked within the institutional patronage provided by the Madras Music Academy, hailed as a premier national institution, Rukmini Devi worked within the transnational system of patronage provided by the Theosophical Society. While Rukmini Devi taught in her Kalakshetra institution, located on the grounds of the Theosophical Society, and traveled to Europe and America to discharge her responsibilities as the President of the Theosophical Society in Huizen, Balasaraswati worked intermittently within the institutional framework of the Madras Music Academy, traveled to the United States, lived there for short and long periods of time, and offered residencies within the institutional framework of Dance and Ethnomusicology programs in the r96os (see Pattabhiraman and Ramachandran 1984a; Meduri 1996a; Allen 1997). The two women, in other words, were traveling women who lived and worked in different institutional locations within India and abroad, and their career trajectories overlapped only occasionally.

To undertake a critical, comparative examination of the two women's artistic legacies, we must not falsely hierarchize the analytic frame, and exceptionalize T. Balasaraswati in relation to Rukmini Devi. We need to place both in a coeval temporality, that is the frame of Indian modernism, position them as inside-outsiders within it, and describe them as in fact representing two similar but different "iterations of Bharatanatyam" in the I930s. We need to equalize the discursive terrain, precisely because 
identities are constructed within, not outside discourse, and so that we might "understand identities as produced in specific historical and institutional sites, within specific discursive formations and practices, by specific enunciative strategies" (Hall 1996, 4).

\section{Enunciative Strategies}

If Balasaraswati drew on the rich musical legacy of her family to provide a distinguishing place for herself in the revival, Rukmini Devi foregrounded the musical traditions of the galaxy of traditional male teachers that she gathered in her institution and gave herself a new, enunciative position in the revival. Both women enlarged their individual identities by shouldering the weight of a larger collectivity, which they hailed variously as tradition, ancestry, and historical legacy. Why did the two women carry this weight of history on their backs? Why could they not shrug it off and speak freely as modern American dancers did in Europe and America of the I930s?

Neither Allen nor O'Shea theorize this burden of the reinvented past that the two women carried on their backs, a burden emerging not from the stable core of the self, but from the contingency of the institutional and political context of Indian nationalism and international Orientalism in which they were speaking, writing, and dancing. Both writers simply essentialize the identities of the two women by assuming a foundational theory of identity for them premised on unitary theories of caste and class, and articulate them as knowing subjects working within a theory of intentionality. Gyan Prakash explains that "the foundational view of identity assumes that history is ultimately founded in and represented through some identity - individual, class, or structure-which resists further decomposition into heterogeneity" (I990, 393). Both Allen and O'Shea develop this foundational theory of identity by unreflexively positioning Balasaraswati and Rukmini Devi within the tradition/change binary.

Again, my main concern here is not to dispute O'Shea or Allen's misrepresentations, but to point to the inadequacies in the tradition/change model of social change that they deploy. At the moment of the revival in the I930s, the Sadir dance tradition was, in fact, represented by three different sets of "traditional people": male dance teachers represented a version of the devadasi Sadir; "ritually dedicated" devadasi women like Gowri Amma, represented their own version of Sadir; and T. Balasaraswati, the inside-outsider to devadasi traditions represented a version of Sadir that she had learned from her male and female teachers.

Should we describe all three sets of "traditional practitioners" as insiders? Or were they all really inside-outsiders because they were all representing Sadir in the new name of Bharatanatyam and negotiating with the uneven processes of anticolonial modernism in the I930s? Who possessed the authentic tradition, and what indeed was "tradition" and "authenticity" in the postcolonial context of the I93os?

Whether the central figure is Rukmini Devi or Balasaraswati there is, as James Clifford points out, no politically innocent methodology for intercultural interpretation. "Some strategy of localization is inevitable if significantly different ways of life are 
to be represented. But local in whose terms? How is significant difference politically articulated? Who determines where and when a community draws its lines, names its insiders and outsiders? These are far reaching issues" (1997, I9).

The political question raised by Clifford is germane to our discussion because there are no more than a handful of students practicing the Balasaraswati style of dance in India (see Meduri 2005, 2I4-223). Yet Balasarawati has a sizeable number of students in the US because she taught dance in Ethnomusicology and Dance Departments in the United States (see Cowdery 1995). In contrast, Rukmini Devi's student family is dispersed all over India and the world. Who is the "insider" and who is the "outsider"? Why is this question about insiders and outsiders being raised by American scholars in the United States and not in India? Since Rukmini Devi and T. Balasaraswati are no more, who needs identity today?

\section{Conclusion}

I have sketched the story of Rukmini Devi as a global-Indian story in this special issue on South Asian Dance not because it is the apposite thing to do in the present intellectual climate when we are all worrying the questions of globalization and the arrival of the contemporary in Indian dance practice. Rukmini Devi's global Indian story acquires a historical charge because we have neither described her transnational vision, nor the unique manner in which she contemporized Bharatanatyam with adequate sophistication. ${ }^{24}$

I have outlined her global story in order to urge more general comparative studies of Indian dance, which will trace the similarities and differences between Ballet and $\mathrm{Ka}$ lakshetra Bharatanatyam. It is this double sited interactional history, one that engaged dialogically with colonial modernity, on the one hand, and with local Indian traditions, on the other, that needs to be placed on the research agenda of South Asian dance scholarship in the United States.

It is true that Rukmini Devi's art and education movement fed into the hegemonic forces that marginalized devadasi practitioners. Yet it is her art and education movement that also enables us today to rehistoricize and reconceptualize emergent "Third World" dance forms and cultural negotiations not as "thin replicas of an experience we in the west are connoisseurs of 'always already' but as one in which the Euro-American experience is significant but neither singular nor always the exemplary center" (Appadurai I988, I).

\section{Notes}

I. I am indebted to all my mentors in the Department of Performance Studies: Richard Schechner, my advisor, Peggy Phelan, Barbara Kirshenblatt-Gimblett and Mick Taussig, for encouraging and supporting my work in the Department of Performance Studies, Tisch School of the Arts, New York University. I enrolled in the Department to study the socio-political history of Bharatnatyam, the dance that 
I had learned from childhood and which I had performed as a professional dancer both on the national and international stage. I desired specifically to understand the regional, national, and transnational history of the dance, and began to develop a postcolonial perspective to understand the revival and transnationalization of Bharatanatyam (1988; 1996). For accounts describing the pioneering research of scholars working at the University of Roehampton, see Andree Grau (2002; 2004); Allesandra Iyer (1997; 2003); and Stacey Prickett (2004).

2. Drawing on the interdisciplinary research of scholars like Amrit Srinivasan (1983; 1985); Fredrique Marglin (1985); Saskia Kersenboom-Story (1987); Kay Jordan (1989); Susie Tharu and K.Lalitha (I993); Tejaswini Niranjana, P. Sudesh, and Vivek Dhareshwar (1993), dance scholars in the United States endeavored to articulate a postcolonial research initiative for Bharatanatyam. In the first stage of the development of South Asian dance studies in the United States, there were very few scholars working in the area. See Avanthi Meduri (1988; 1990; 1992; 1996), Uttara Coorlawala (I992; 1996), and Anne-Marie Gaston (1992; 1996).

3. See Meduri (I996, I-IIo); Davesh Soneji (I999); Jeffrey Spear and Meduri (2004). All three essays deal specifically with the hybridization and transnationalization of devadasi dance practices. Drawing on the first part of my thesis, dealing with devadasis, I also authored and acted in a postcolonial play entitled God Has Changed His Name. Premiered in India in 1997, the bilingual play was presented in twenty-four cities across India, and staged in mainstream theatre venues, schools, and colleges of India. A regional (Tamil) version of the play was staged in 1998. See Seagull Theatre Quarterly (1999, 29-5I), for a discussion about the play and issues raised in the performance.
4. It was Amrit Srinivasan (1983, 73-99) who first drew attention to the World Teacher and World Mother movements in the I980s. I elaborated on questions relating to Rukmini Devi's agency (I996, 277-299). Mathew Allen (1997, 70-74) also provides a neat and elegant summary of the two transnational movements. In Translocal Modernities (forthcoming), I evolve an antiessentialist theory of identity focusing on the enunciation of the three names: Rukmini-Devi-Arundale.

5. See Meduri (1996, 406-458) and Pallabi Chakravorty (1998, 107-I20) for a discussion pertaining to the institutionalization of the arts. See also Mathew Allen's elegant summary of my research, embellished by his own innovative research into the music revival (I997, 63-Ioo).

6. If Rukmini Devi was celebrated as a pioneer and heroine who saved the dance of Bharatanatyam before her demise in I986, she was hailed as an "appropriator" in Indian and United States dance scholarship of the i99os. See Srinivasan (1983, 73-99), and Allen (1997, 63-100). By 2000, the historical story of the dance revival was staged as a struggle between two women inscribed in two different caste and class backgrounds: "Brahmin Rukmini Devi and devadasi T. Balasasaraswati” (O’Shea 200I, 24). In the second part of the paper, I describe the global contexts in which the two women worked and explain why we need to rethink the revival story of Bharatanatyam outside the limiting framework of Indian nationalism as such.

7. In Translocal Modernities (forthcoming), I discuss the grooming of Rukmini Devi within the transnational worldview of the Theosophical Society, and how she replicated the Divine Dancer legacies of Isadora Duncan and Ruth St. Denis in what I describe as the first stage of her enunciation between I920-I933.

8. See (Ramnarayan 1984a, I7-29). See 
also the Birth Centenary volume, edited by Shakuntala Ramani (2003), specifically the essay entitled "Rukmini on Herself."

9. See my essay (2005, 195-223) on the staging techniques that Rukmini Devi used in 1935 and how she developed a multifaceted, dramaturgical aesthetic for Bharatanatyam by incorporating the staged aesthetic into the institutional goals of her Kalakshetra institution.

Io. Rukmini Devi combined the visions of the two centers and articulated a transnational art and education movement known as "Education without Fear, and Art without Vulgarity" (Nachiappan 200I, I8). C. Nachiappan, who worked with Rukmini Devi from 1940, until her demise in I986, describes the transnational art education movement in this way: "Arts were an integral part of the school system and enabled great experiments in education, like introducing the Dolton system of education in which children learnt by themselves without too much interference from teachers. It is here that Dr. Montessori conducted her first Indian Montessori course and experimented with the advanced Montessori Method for 6-I2 year old children" (200I, I8).

II. See Silver Jubilee Report of Kalakshetra (1936-I96I), for a brief discussion of the five institutions.

I2. By the I940s, Kalakshetra also became famous for the galaxy of traditional teachers that Rukmini Devi gathered in her institution (Ramani 2003). Since the traditional teachers recruited in the institution were well versed in such diverse fields as dance, music, painting, weaving, Sanskrit language, drama and folk arts, Rukmini Devi urged them to teach from within their fields of expertise and specialization. She thus envisioned a multidisciplinary, cosmopolitan institution of the kind unknown in South India in the I940s: one in which education, crafts, music, dance, painting, and research coexisted to constitute what Kamaladevi Chattopadyay described as a "vision of totality" (1986, 5).

I3. Dr. Besant described the world movements at the Star Congress, Ommen, in I925, and again in the Golden Jubilee Celebrations of the Theosophical Society, held at the international headquarters in India, I928. See Annie Besant (I925); Ranson (I928, 467-472) for a fuller elaboration of Besant's World vision. But Rukmini Devi indigenized Annie Besant's global movements and developed what I describe as her ACE (arts, culture and education) movement, which was both continuous with and different from Besant's transnational vision. Also see Translocal Modernities (forthcoming).

I4. See fourth President Jinarajadasa's official statement on the Disassociation Policy in The Indian Theosophist (1950, 19-23). See also the June issue of The Indian Theosophist, which is practically a Disassociation Policy number. I discuss the Policy and describe its impact on Rukmini Devi's global vision in Translocal Modernities (forthcoming).

15. See Besant Cultural Nerws Bulletin (1949). On the last page of each and every Art and Education journal that Rukmini Devi edited and published in the I95Os is inscribed this note: "The Besant Cultural Trust is the name given to the group of following institutions: Besant Theosophical High School, Kalakshetra-College of Fine Arts, Arundale Training Centre for Teachers, Hostels and Dr. Swaminath Iyer Library. All these institutions come under two different Trusts: The Besant Theosophical High School, The Arundale Training Center and the Hostels under the Besant Centenary Trust; Kalakshetra, College of Fine Arts and Dr. Swaminath Iyer Library under Kalakshetra. Therefore the Besant Cultural Centre has no legal identity 
but is composed of an organic and vital connection in their common activity and in the give and take between each of these institutions."

I6. The Government of India requested Rukmini Devi to lead cultural delegations to foreign countries, chair national committees set up for the incorporation of art and culture into higher education, and honored her with numerous national awards including the Padma Bhushan and the Sangeet Natak Akademi in the I95os. She was also nominated to serve as the first woman legislature in the upper house of the Indian Parliament, immediately after the constitution of the nation-state in 1950 . She completed two terms in Parliament, moved a bill for the Prevention of Cruelty to Animals, and received the Prani Mitra or Animal Lover Award in I968. The Royal Society for the Prevention of Cruelty to Animals, London, likewise awarded Rukmini Devi with the Queen Victoria Silver Medal in 1958, and the Council of the World Federation for the Protection of Animals, The Hague, added her name to their Roll of Honor in 1959. Rukmini Devi was also nominated as candidate to serve as President of India in 1977, but she refused the nomination.

I7. As a researcher who combined both perspectives in the enunciative phase of postcolonial dance studies in the I980s, I admit candidly to the many invaluable insights to be gained in describing Bharatanatyam exclusively from within an Indian national or area studies perspective. The local framework enabled me to understand why Rukmini Devi Arundale revived Bharatanatyam from within what I have elsewhere described as her temple stage aesthetic and why that symbolic structure continues to prevail in contemporary local, global, and diasporic practices of Bharatnatyam today. See Meduri (2005, 3-29) and Translocal Modernites (forthcoming).
I8. In this context, I want to thank Dwight Conquergood and Margaret Drewal for encouraging me to teach the above mentioned "experimental" courses in the Department of Performance Studies at NU.

I9. In my thesis (1996), I focused my discussion specifically on the historic moment when Balasaraswati questioned Rukmini Devi in the first national dance seminar of I958 (1996, 406-458), and tried to think the agency of the two women outside foundational theories of caste and class identity, and beyond the category of "insiders" and "outsiders" simultaneously.

20. In my dissertation, I identified the I943 moment as representing a problematic beginning in the history of the development of the Kalakshetra institution (I996, 366-405), and described it as an ambivalent moment by pointing to the incorporation of a devadasi by the name of Saradamabal who began teaching in the institution at that time. The 1943 separation from male teachers was empowering from a gender point of view because Rukmini Devi evolved a new "dancer-teacher" category in that moment of crisis. After 1943, Kalakshetra students learned both the dance vocabulary and also the techniques for conducting dance recitals, which had been preserved exclusively in the custody of male dance teachers till the r940s.

2I. See Kersenboom-Story (1987) for full explication describing the dedication rites and rituals of devadasis, specifically their marriage to temple-gods and the lifestyle practices that evolve from the dedication ritual.

22. See Kersenboom-Story's discussion about the unraveling of devadasi traditions, which she marks in $1856(1987,47)$. See also my discussion about the difficulties in marking the precise moment when the artistic practices of devadasis were reconfigured (1996, 27-3I). 
23. Although it is not clear who renamed the dance, most critics attribute the renaming to $V$. Raghavan, the eminent scholar of Sanskrit studies. See my discussion about the new name Bharatanatyam given to the dance in r930s (1996, 267-276). Also see Coorlawala (1996), Veena Ramphal (2005), and Meduri (2005, I98-20I) for different discussions about the importance of the name.

24. As part of my three-year postdoctoral research in India between 200I-2004, I endeavored to develop a transnational research initiative for Bharatanatyam by using Rukmini Devi as case study. During this time, I curated Rukmini Devi's photo archive, which I presented in New Delhi, Calcutta, Kuala Lumpur, Singapore, Colombo, London, Tokyo, and Melbourne. I also collaborated with Professor Kathy Foley at the University of California, Santa Cruz, and developed an intercultural performance script titled Shattering The Silence: The Three Women of the Theosophical Society. The piece positions Rukmini Devi within the global discourses of the Theosophical Society and describes her as the one who carried the torch for the feminist legacy of the Theosophical Society in India. To complement this research, I developed another performance script entitled Birds of the Banyan Tree, which dramatized how Rukmini Devi kept the global flame alive in her life and work in India. The play was presented as part of the Birth Centenary Celebrations in New Delhi, Bangalore, and Chennai in March 2004. In April 2004, I taught two courses on the globalization of Bharatanatyam, with a focus on Rukmini Devi, in the Department of Theatre Arts at Santa Cruz, developed a short script entitled Birth of Bharatanatyam, and staged it in collaboration with students in the Second Stage Theatre at UCSC in June 2004.

\section{Works Cited}

Allen, M. H. I997. "Rewriting the Script for South Indian Dance." The Drama Review 41: 63-100.

Appadurai, Arjun. I988. "Why Public Culture?" Public Culture I (I): 5-Io.

- 1996. Modernity at Large: Cultural Dimensions of Globalization. Minneapolis: University of Minnesota Press.

Besant, Annie. 1925. Star Congress at Ommen. Adyar: Theosophical Publishing House.

Chakravorty, Pallabi. I998. "Dance Hegemony and Nation: The Construction of Classical Indian Dance." South Asia 2r: IO7-I2O.

. 2000/200I. "From Interculturalism to Historicism: Reflections on Classical Indian Dance." Dance Research Journal 32 (2) (Winter): I08-II9.

Chatttopadhyay, Kamaladevi. I986. "A Vision of Totality." Kalakshetra Quarterly (Madras): 8 (3-4): 5-6.

Clifford, James. I997. Routes: Travel and Translation in the Late Twentieth Century. Cambridge: Harvard University Press.

Coorlawala, Uttara A. 1992. "Ruth St Denis and India's Dance Renaissance.” Dance Chronicle I5: I23-I45.

- I996. "The Birth of Bharatanatyam and the Sanskritized Body." The Body in Dance: Modes of Inquiry: Conference Proceedings of the Congress on Research in Dance.

Cowdery, James R. 1995. "The American Students of Balasaraswati. " UCLA Journal of Dance Ethnology I9: 50-57.

Cvetkovich, Ann and Douglas Kellner, eds. 1997. "Introduction: Thinking Global and Local." In Articulating the Global and the Local: Globalization and Cultural Studies, I-30. A Division of Harper Collins Publishers: Westview Press. Devi, Rukmini. 1936. "The International 
Academy of the Arts.” Adyar Pamphlet, no 208. Madras: The Theosophical Publishing House.

- I949. The Besant Cultural Centre

Nerws. (March): I-I2

- I96o. The Besant Cultural Centre.

Adyar: Kalakshetra Publications.

Erdman, Joan. I987. "Uday Shankar in the

West.” $T D R_{3 \mathrm{I}}$ (I) ( $\left.\mathrm{T}_{\mathrm{I}}\right): \mathrm{I}_{4}-88$.

- I996. "Dance Discourses: Re-

thinking the History of the Oriental

Dance." In Moving Worlds: Rewriting

Dance. Edited by Gay Morris. New

York: Routledge.

Fabian, Johannes. 1983. Time and the Other:

How Anthropology Makes its Object. NY:

Columbia University Press.

Featherston, Mike. 1990. "Global Culture: An Introduction.” In Global Culture: Nationalism, Globalization and Modernity. Edited by Mike Featherstone. London, New Delhi: Sage Publications.

Gaston, Anne-Marie. 1996. Bharatanatyam from Temple to Theatre. New Delhi. Manohar.

Grau, Andree. 2002. "South Asian Dance:

The British Experience: Negotiating Cultural Identity through Dance." Unpublished Report, Leverhulme Research Grant n. F/569/D.

. 2004. "Dance and Postcolonial

Theory: South Asian Dance in Britain."

In Dance in South Asia: New Approaches,

Politics and Aesthetics. Edited by Pallabi

Chakravorty, 23-30. Swarthmore

College.

Hall, Stuart. 1996. "Introduction: Who

Needs Identity." In Questions of Cultural

Identity. Edited by Stuart Hall and Paul

Du Gay, I-I8. London/Thousand

Oaks/New Delhi: Sage Publications.

Iyer, Allesandra, ed. 1997. South Asian

Dance: The British Experience. London:

Harwood Academic Publishing.

- 2003. "Classicism, Post-Classicism and Ranjabati Sircar's Work: Re-

Defining the Terms of Indian Contemporary Dance Discourses." South Asia

Research, 23 (2): I53-I69.

Jinarajadasa, C. I950. "The Disassociation

Policy." The Indian Theosophist 47 (8)

(February): 19-23.

Kersenboom-Story, Saskia. 1987. Devadasi

Tradition in South India. Delhi: Motilal

Banarasidass.

King, Anthony, ed. 1997. "Introduction:

Spaces of Culture, Spaces of Knowl-

edge." In Culture, Globalization and the

World System: Contemporary Conditions

for the Representation of Identity, $\mathrm{I}^{-} 39$.

Minneapolis: University of Minnesota

Press.

Kothari, Sunil, ed. 1979. Bharatanatyam:

Indian Classical Dance Art. Bombay:

Marg Publications.

Marglin, Frederique Appfel. 1985. "Wives

of the God-King." Rituals of the Devadasis of Puri. New Delhi: Oxford University Press.

Meduri, Avanthi. I988. "Bharatanatyam: What Are You?" Asian Theatre Journal 5 (I): I-22.

- 1990. "History as Image: Mimesis in Bharatanatyam." Fifth Hong Kong International Dance Conference, July I5-28: Conference Papers II, K-Z:

I07-I25, Hong Kong: Hong Kong Academy of Performing Arts.

- r996a. "Nation, Woman, Representation: The Sutured History of the Devadasi and Her Dance.” Ph.D. dissertation, New York University.

- 1996b. "Modern History of

Bharatanatyam: Vibrant Form or Export

Commodity." Voices I (3): 53-57.

- 1997. "They Revived A Tradition."

Hindu (Chennai) (September 5, 30).

- 20ora. "Talibanization of the Per-

forming Arts." The Hindu (Chennai)

(Dec. 18).

- 20oIb. "Bharatanatyam-What are 
You?" In Dance History Reader: Moving History/Dancing Cultures. Edited by Ann Cooper Albright and Ann Dils, Io3-I33. Middletown, CT: Wesleyan University Press.

- 2003a. "Multiple Pleasures." In

Taken by Surprise: A Dance Improvization Reader. Edited by Ann Cooper Albright and David Gere, I4I-I5O. Middletown, CT: Wesleyan University Press.

- 2003b. "Western Feminist Theory, Asian Indian Performance and a Notion of Agency.” In Performance: Critical Concepts in Literary and Cultural Studies. Edited by Philip Auslander, London, New York: Routledge.

- 2004. "Knowing the Dancer: East meets West." Victorian Literature and Culture, 32 (2): $435^{-448}$ [This essay is co-authored with Jeffrey Spear].

- 2005a. "Introduction: A Critical

Overview." In Rukmini Devi: A Visionary Architect of Indian Culture and the Performing Arts, 3-29. Edited by Avanthi Meduri, New Delhi: Motilal Banarasidass.

- 2005b. "Rukmini Devi and Sanskritization: A Performance Perspective." In Rukmini Devi: A Visionary Architect of Indian Culture and the Performing Arts, 195-223. Edited by Avanthi Meduri, New Delhi: Motilal Banarasidass.

- 2005c. God Has Changed His Name. (Play forthcoming) Calcutta: Seagull Press.

- 2005 d. Birds of The Banyan Tree, (Play forthcoming). Calcuttta: Seagull Press.

- (forthcoming). Translocal Modernities: Cultural Identity, Aesthetics and Cosmopolitanism in Bharatanatyam. Middletown, CT: Wesleyan University Press.

Menon, Narayana. 1986. "Rukmini Devi and the Making of Kalakshetra." Kalak- shetra Quarterly (Madras): $8(3-4)$ :

93-94.

Menon, Sankara. 196I. Report on Kalakshetra: 1936-196r. Adyar: Kalakshetra.

Mirsepassi Ali, Basu Amrita, and Weaver Frederick, eds. 2003. Localizing Knowledge in a Globalizing World: Recasting the Area Studies Debate. New York: Syracuse University Press.

Nachiappan, C. 200I. Rukmini Devi: Bharatanatya. Chennai: Kalakshetra Publications.

Niranjana, Tejaswini, P. Sudir and Vivek Dhareshwar, eds. 1993. Interrogating Modernity: Culture and Colonialism in India. Calcutta: Seagull Books.

O'Shea, Janet. 1998. “Traditional Indian Dance and the Making of Interpretive Communities." Asian Theatre Journal I5 (I) (Spring): $45^{-63}$.

- 200I. "At Home in the World: Bharata Natyam's Transnational Traditions." Ph.D. dissertation, UC Riverside.

Pattabhiraman, N. and Anandhi Ramachandran. 1984a. "The Whole World in Her Hands," Part I. Sruti 4 (January/ February): I7-3I.

- i984b. "The Whole World in Her Hands," Part 2. Sruti 5 (March): $17-32$. Pillai, Shanti. 2002. "Rethinking Global Indian Dance through Local Eyes: The Contemporary Bharatanatyam Scene in Chennai." Dance Research Journal 34 (2) (Winter): I4-29.

Prakash, Gyan. I990. "Writing PostOrientalist Histories of the Third World: Perspectives from Indian Historiography." Comparative Studies in Society and History 32 (2): 383-408.

Prickett, Stacey. 2004. "Techniques and Institutions: The Transformation of British Dance Tradition through South Asian Dance." Dance Research Journal, 22 (I): I-2I. 
Ramphal, Veena. 2005. "Reinvoking Rukmini Devi: Questions from a Dance Maker in Britain." In Rukmini Devi: A Visionary Architect of Indian Culture and the Performing Arts, 247-258. Edited by Avanthi Meduri. New Delhi: Motilal Banarasidass.

Ramanarayan, Gowri. I984a. "Rukmini Devi: A Quest for Beauty, a Profile," Part I, Sruti 8 (June): I7-29.

-. I984b. "Rukmini Devi: Dancer and Reformer, A Profile.” Sruti 9 (July): I7-29.

-. I984c. "Rukmini Devi: Restoration and Creation, A Profile.” Sruti io (August): $26-38$.

Ramani, Shakuntala, ed. 2003. Rukmini Devi Arundale: Rukmini Devi Birth Centenary Commemorative Volume ( $A$ Rukmini Devi Centenary Publication). Chennai: Kalakshetra Foundation. - 2003. Shraddanjali: Brief Pen Portraits of Great People who Laid the Foundation of Kalakshetra (A Rukmini Devi Birth Centenary Publication). Chennai: Kalakshetra Foundation.

Ranson, Josephine. 1938. A Short History of The Theosophical Society. Madras: The Theosophical Publishing House.

Robertson, Roland. I995. "Glocalization: Time-Space and HomogenietyHeterogenity." In Global Modernities. Edited by Mike Featherston, Scott
Lash, and Robertson Roland, 25-68. London/Thousand Oaks/New Delhi: Sage Publications.

Sarada, S. 1985. Kalakshetra Rukmini Devi: Reminiscences. Madras: Kala Mandir Trust.

Soneji, Devesh. 1999. "The Catir Composition of the Thanjavur Brothers." (unpublished paper).

Srinivasan, Amrit. 1983. "The Hindu Temple Dancer: Prostitute or Nun?” Cambridge Anthopology 8 (I): 73-99.

- I984. "Temple Prostitution and Community Reform: An Examination of the Ethnographic, Historical and Textual Content of the Devadasis of Tamil Nadu, South India.” Ph.D. dissertation, Cambridge.

- I985. "Reform and Revival: The Devadasi and Her Dance." Economic and Political Weekly 20 (44) (November): 1869-1876.

Tharu, Susie and K. Lalita, eds. 1993. Women Writing In India: Vol 2, The 2oth Century. New York: The Feminist Press at the City University of New York. Vatsyayan, Kapila. 1968. Classical Indian Dance in Literature and the Arts. New Delhi: Sangeet Natak Akademi.

- 1974. Indian Classical Dance. New

Delhi: Ministry of Information and Broadcasting. 
Copyright of Dance Research Journal is the property of Congress on Research in Dance and its content may not be copied or emailed to multiple sites or posted to a listserv without the copyright holder's express written permission. However, users may print, download, or email articles for individual use. 